EASTERN REVIEW 2019, T. 8

\author{
Ekaterina Rezanova \\ (iD) https://orcid.org/0000-0003-3573-7101 \\ Belarusian Institute for Strategic Research, Belarus \\ Department of Sociological Studies \\ e-mail: ekaterina-rezanova@yandex.ru
}

\title{
The social policy of Belarus and the development of human potential: Problems and solutions
}

\begin{abstract}
The article is devoted to the analysis of the directions and mechanisms of adapting the social policy of Belarus to the demographic, migration, communication and technological challenges of modern society. The purpose of the article is to search for social policy mechanisms aimed at developing human potential and stimulating the social activity of citizens. The author analyses the directions of the state's social policy in the absence of the reproduction of labor resources, an increase in the demographic burden on the ablebodied population, an uneven distribution of labor resources, the emigration of skilled personnel, growth in automation and robotization of production, and a growing need to build effective communication between the government and the population. The article provides an extensive analysis of statistical information, sociological research data, the legislative framework, methods and social technologies of social policy.

As a result of the study the author comes to the conclusion that it is necessary to search for new mechanisms for implementing social policy in various fields. Therefore, in the field of demography, it is advisable to search for indirect measures to increase social guarantees for women in order to stimulate fertility, and transform the pension system in order to reduce the demographic burden on the working population. In the field of migration, it is advisable to take government action to prevent the outflow of highly qualified specialists abroad and to return of students who have received education abroad. In the field of social and labor relations existing personnel technologists should be improved and objective methods for evaluating the effectiveness of employees based on a competency-based approach should be introduced. In the field of communication between society and the state it is necessary to inform the public about the current state policy and to organize public discussions of the state initiatives before making them.
\end{abstract}

Keywords: social policy, human potential, social technologies, migration, communication. 


\section{Introduction}

Human potential is the main instrument of the socio-economic development of society. The key goal of a state's social policy is to create conditions for the comprehensive and harmonious development of all members of society; providing them with social rights and guarantees in various life situations. The social policy of the state should be aimed at improving public welfare; raising the standard of living of the population; ensuring social and political stability; and encouraging both social partnerships and social harmony in the country. In this way, it is possible to form a socially stable and highly developed society in which there is no poverty, nor sharp social contrasts. In other words, a necessary and sufficient level of social protection of the population has been achieved. There exist such types of social policy as paternalistic, liberal, corporate and others. They differ on the mechanisms that are involved in the realization of the social policy of the state and the type of methods which are used for providing citizens with their needs.

In the framework of the paternalistic approach, the main role in solving social issues belongs to state institutions, the principle of state responsibility is overriding. The state is centrally responsible for the socio-economic status of citizens; all other subjects of social policy act on behalf of the state and under its control. The financial basis of the paternalistic model is the means of the state budget and the budgets of state enterprises. Distinctive features of the paternalistic model are: centralized regulation of the social sphere; crowding out all sources of social policy except the state; the poor development of market relations and competition in the social sphere; a general orientation to guaranteed employment provided by administrative levers; a lack of a real labour market; the presence of a significant level of hidden unemployment in the form of inefficiently used labour; the inefficiency of social sphere management; a low level of social services; the formation of social passivity and dependent moods. Paternalism is now widely used for sound state intervention in the life of citizens (Chubarova, 2019: 28).

This model implements the principle of equality in the consumption of material and social goods and services, as well as their general accessibility, which ensures the achievement of a high degree of social alignment (Lozovova, Nemashkalova, 2014: 124). The positive side of the paternalistic approach is a stable income level for the bulk of the population (guaranteed wages, stable prices, lack of unemployment, universal social support, a certain list of free social services). Very often paternalistic support is needed not only by individuals who find themselves in difficult life situations, but whole sectors of activity that affect the successful functioning of the society often need state support (Plishkevich, 2019: 101).

At the same time, the negative side is the lack of stimulation of labour and no personal responsibility for one's social situation; the shortage of goods 
and services; the planned distribution of consumer goods and housing; and the underdevelopment of the private sector of the economy. The paternalistic model of social policy is characteristic of the countries that were part of the USSR and embarked on the path of socialist development. Some countries are trying to get away from the paternalistic path and develop milder forms in social policy, such as libertarian paternalism. However, such negative aspects of paternalism such as interference in a person's choice are preserved (Chubarova, 2019: 29).

Within the corporate model of social policy, all responsibility for the fate of an employee lies with the corporation, enterprise, organization or institution where the employee works. Enterprises have their own extensive social infrastructure and their own social insurance funds. Organizations encourage workers to make the maximum labour contribution and offer them various types of social guarantees in the form of pensions, and partial payment of medical and educational services (advanced training). The financial basis of social policy in the corporate model is the funds of enterprises and corporate social funds. This model of social policy is typical for countries such as Germany, France, Japan, amongst others (Lozovova, Nemashkalova, 2014: 126).

The liberal model of social policy presupposes the principle of the personal responsibility of each member of society for their own fate and the fate of their family. The role of state structures in the direct implementation of social policy is minimized, and the main subjects of social policy are citizens, family and various non-governmental organizations. The financial basis for the implementation of social programs in the framework of the liberal model is private savings and private insurance. The provision and cost of social services directly depend on the size of insurance premiums in the system of private social insurance. The state is only responsible for maintaining the minimum incomes of citizens and for the well-being of the weakest and most disadvantaged segments of the population. The state creates the conditions for the formation in the individual and public consciousness of a feeling of high personal responsibility for their social well-being. The state is not a source of social benefits for citizens, but a guarantor of its rights and freedoms. This model of the social policy of the state is characteristic of the USA, Great Britain, Canada, Ireland, amongst other countries (Lozovova, Nemashkalova, 2014: 121). The advantage of the liberal approach is its orientation to uncovering people's abilities in the interests of increasing their consumption and self-realization; saving budget funds and redistributing resources in the interests of social support for those in need. The disadvantages are manifested in the significant differences between the level of consumption of economically strong and weak households.

The social policy of Belarus is mainly paternalistic. Social programs come down to the distribution of benefits and additional payments, citizens' opportunities are limited, dependent moods are fixed, and the development of human potential is restrained. Over time, the paternalistic approach has yielded 
positive results in various areas of the social sphere. However, new socio-economic conditions create the need to search for appropriate mechanisms and technologies in the implementation of social policy in the demographic, migration, communication and social-labour spheres.

\section{Social policy in the sphere of demography}

In the demographic sphere, it is necessary to solve a number of important problems. The demographic challenge is primarily associated with the reduction and ageing of the population. The problem of depopulation has been relevant for Belarus since 1993, and since then, mortality has exceeded the birth rate annually. Over the past twenty years, the population has declined by half a million people. Fertility is also constantly declining: 94,042 children were born in 2018 in Belarus. This is $9 \%$ less than in 2017. The number of births in the first half of 2019 also decreased compared to the first half of 2018 by $9 \%$.

At the same time, mortality has increased: last year 742 more people died than in 2017. As a result, the natural population decline was 26,011 people, which is by 9,236 more people than the previous year (Demographic yearbook..., 2019).

Table 1. Natural increase in 2015-2018

\begin{tabular}{|c|c|c|c|}
\hline Year & Number of births, person & Number of dead, person & Natural decline, person \\
\hline 2015 & 119,028 & 120,026 & -998 \\
\hline 2016 & 117,779 & 119,379 & $-1,600$ \\
\hline 2017 & 102,556 & 119,311 & $-1,6775$ \\
\hline 2018 & 94,042 & 120,053 & $-26,011$ \\
\hline
\end{tabular}

Source: based on author's calculations.

In the nearest future, the process of depopulation will continue as we enter into the reproductive period of the generation of women who were born in the 1990 s, which as already mentioned is smaller than previous generations.

Belarus implements many state programs to stimulate fertility. Women are granted parental leave for 3 years. Such long parental leave is also provided in Russia, Moldova, Ukraine, and Kazakhstan. However, Russia has introduced restrictions on the payment of childcare benefits over one and a half years. In Western Europe, parental leave is significantly shorter (The demographic situation..., 2019).

Families with many children receive preferential loans and support in the construction of housing. In the next two years, it is planned to significantly reduce the number of large families that need to improve their living conditions. Since 2015, 
Belarus has been implementing a program called "family capital": it is envisaged that funds will be credited to a deposit account for parents with many children at the birth (adoption) of a third and subsequent children. When the child is 18 years old, these funds can be spent on education, home improvement or medical care.

At the same time, measures taken at the state level to improve the demographic situation are not yet producing sustainable results. Currently, young families often plan to have children at a later age. So, the average age of a mother in 2019 was 29 years, while in 2000 the average age of a mother was 25 years. This is due to the fact that young people prefer career growth, travel and entertainment (Demographic yearbook..., 2019).

The next demographic challenge is the increase in the total population of the share of people over working age. Whilst the share of this cohort was $21 \%$ in 2000 , by 2019 it had reached 25\%; this despite a phased increase in the retirement age. At the same time, the number of people employed in the economy is constantly decreasing: since 2010, the employed population has decreased by $8 \%$. As a percentage, the proportion of pensioners to the number of employed population was $52 \%$ in 2010 ; rising to $60 \%$ in 2019 . A constantly decreasing number of people employed in the economy cannot ensure the payment of pensions to an ever-growing number of pensioners, which leads to a budget deficit in the Social Security Fund (In Belarus..., 2017). It should be noted that the bankruptcy of pension funds is a worldwide problem, due to increased life expectancy and low return on the investment of pension funds.

In order to reduce the burden on the Social Security Fund in Belarus, a gradual increase in the retirement age has been carried out since 2016. By 2022, men will retire at 63 years old, and women at 58 years old. The state plans to continue the policy of raising the retirement age with regard to women in order to ensure gender equality in Belarus. In addition, the life expectancy of retired women is much longer than that of men (the average retirement period for women is 23 years, compared to 8 years for men). In many foreign countries (Finland, Germany, France, Norway, Denmark, Greece, Portugal, etc.) men and women retire at the same age. It is clear therefore that only an increase in the retirement age can solve this problem.

Changing the mechanism for calculating pension payments to Belarusians is also relevant today. The procedure for calculating the amount of old-age pensions is regulated by the Law of the Republic of Belarus "On Pension Provision" (Law of Republic of Belarus..., 1992). The size of the retirement pension depends on the length of service and the level of wages from which the payment of insurance contributions for pension provision was made. However, when calculating the labour pension in full, only $130 \%$ of the average salary of employees is taken into account, and the rest is taken into account with decreasing factors. Thus, the funds contributed into the Social Security Fund by different citizens, during their period of work, may differ by a factor of ten, and yet the accrued pension will be 
approximately the same. This leads to equalization of income of most retirees and deprives them of motivation in long and intensive work.

A funded pension insurance system is being developed in Belarus now. Two insurance companies are engaged in voluntary pension insurance: the state company Stravita and the private company Priorlife. Citizens of Belarus can make contributions to the savings fund at a certain percentage. The accumulated amount is returned immediately or in parts when they reach retirement age. At the same time, pension insurance is not widespread: only $4 \%$ of the employed population is covered by these types of insurance. The reason for this is the distrust of the population in any long-term savings projects after the number of instances of inflation and devaluations that have occurred in the country over the past decades. Pension programs are designed for a long time, and what will happen in the economy over this period is difficult to predict. In Belarus, pension insurance is carried out on a voluntary basis, while in some foreign countries, compulsory pension insurance is part of the state social policy.

\section{Social policy in the sphere of migration}

The migration challenge is associated both with increased labour and educational emigration, and with the growth of internal migration to the central part of the country. The reasons for the growth of labour migration abroad are as follows: the active policy of foreign countries to attract missing labour resources (a system of benefits and preferences), an open foreign policy of Belarus in the western direction, and encouraging labour and educational mobility. The Law of the Republic of Belarus "On External Labor Migration" was amended to simplify the process of attracting foreign specialists and securing foreigners studying in the universities of our country, but they did not create conditions for securing our highly qualified personnel (Rudak, 2019: 147).

At the same time, it should be noted that the study of migration processes poses a number of problems: the lack of a unified methodological base; the unsatisfactory state of migration statistics significantly limiting the possibilities of analysis; an insufficiently developed system of conducting opinion polls in the field of migration; the politicization and idealization of demographic processes and migration studies (Zagorets, Zagorets, 2019: 74).

The existing methodology for the statistical registration of migrants by state bodies in Belarus allows to accurately register only the number of citizens arriving from other countries (immigrants), and the registration of departing (emigrants); it thus provide only minimum data as emigrants also may include citizens who have changed citizenship and have become a consular register in the country of residence; students who have gone abroad 
to study; temporary labour migrants who have left under contracts that are officially registered by the Department of Citizenship and Migration of the Ministry of Internal Affairs of the Republic of Belarus. At the same time, many migrants are independently looking for work and are not taken into account by official statistics. The lack of accounting for unorganized temporary labour migration leads to a significant distortion of the assessment of the results and consequences of the state migration policy. Government bodies officially declare a positive balance of migration flows, however, scientists who study migration processes using alternative methods repeatedly refute these claims (Zagorets, Zagorets, 2019: 76). For example, research has shown that over the past eight years, the negative balance of migration with Russia for Belarus amounted to more than 69 thousand people. Similar results are obtained by comparing the data of the Belarusian and European statistics: according to the data of the National Statistical Committee of the Republic of Belarus 472 people left Belarus for Poland in 2017. However, according to Eurostat, 42,756 Belarusians received a residence permit in Poland for the same time (Zagorets, Zagorets, 2019: 77).

Whilst earlier external labour migration was mostly towards the Russian Federation, in recent years the western direction has also gained popularity. There is an increase in migration to Poland and Lithuania. Lithuania issued to Belarusians more than six thousand visas in 2018, giving the right to employment. At the beginning of 2018, more than 100 thousand citizens of Belarus (mainly residents of the Brest and Grodno regions) were issued the Pole card. The Pole card makes it possible to obtain an annual long-term visa according to a simplified scheme, open a business in Poland with the same rights as Polish citizens, receive a free education with financial support from the government, and subsequently obtain Polish citizenship. This document also greatly simplifies employment in Poland, eliminating the need to obtain an invitation to work from an employer. An additional reason for moving is a residence permit in Poland. The number of Belarusians who have received this status is also now approaching 100 thousand. Most of this group receive a residence permit for employment.

Belarusians take the third place in the number of labour migrants in Poland (the first - Ukrainians, and the second - Nepalese). According to the Ministry of Family, Labor and Social Protection 8,495 Belarusians left for Poland in order to be employed in 2018 (in 2017 - 6,839 people) (Workers from Belarus..., 2018). Compared to Belarus, more favourable working conditions are offered in Poland for such categories of workers as drivers and builders. Poland today has a huge fleet in the field of international transport and takes a leading position in Europe in this area. At the same time, the huge fleet of vehicles lacks drivers today. Belarusian workers are very appreciated in Poland because of their accuracy, responsibility and decency. 
Moreover, the countries of Europe and the Russian Federation offer highly qualified health professionals from Belarus a higher status and more favourable conditions, in terms of earnings. Among the students of the Belarusian State Medical University, migratory sentiments are widespread: those who have the ability to learn foreign languages are set to travel abroad; those who cannot learn a foreign language plan to leave for Russia. About 200 doctors leave Belarus every year.

In such conditions, the problem of training specialists is aggravated: every year Belarus spends hundreds of millions of dollars on education, but other countries are increasingly using the effectiveness of the education system. It should be noted that the most qualified, enterprising and promising young people leave Belarus, thus there is a loss of the country's human capital. The data of sociological studies show that the proportion of respondents planning to travel abroad, both for the purpose of changing their place of residence and for the purpose of employment, has increased significantly in recent years, especially among young people (Pushkevich, 2018: 309).

Internal labour migration is also a serious problem: more and more people are leaving their native regions for the capital in search of work and a higher level of income. This causes labour redundancy in some regions and a shortage of personnel in others. In particular, the central part of the country - Minsk and the Minsk region accounts for $40 \%$ of the workforce, while, for example, in the Grodno region and the Mogilev region - 10\% each. For example, Maloritsky district ranks 17th in terms of wages among all regions of the Brest region, and 1st place in terms of the number of those who left in search of work (about 700 specialists left the region over the past year).

Experts note that the migration of people to the capital city and the Minsk region is inevitable: in the outer regions there is practically no movement of workers from inefficient to efficient production. Despite some incentives for doing business in small towns, business is poorly developed there. At the same time, attempts to limit the internal migration can provoke a surge in external emigration.

The significant reduction in the number of people employed in agriculture is becoming critical, which is accompanied by low labour productivity, a decrease in the number of people employed in farms, a depletion of the demographic base of the village, and a shortage of qualified personnel. Thus, the number of vacancies for veterinarians in rural areas is more than 100 times the number of registered unemployed for this profession, 233 vacancies for 1 unemployed doctor, 377 vacancies for two unemployed nurses, 385 vacancies for two unemployed livestock specialists (Statistics..., 2019). 
Table 2. Supply and demand in the labour market in rural areas (2019)

\begin{tabular}{|l|c|c|}
\hline \multicolumn{1}{|c|}{$\begin{array}{c}\text { Name of professions } \\
\text { and specialities }\end{array}$} & $\begin{array}{c}\text { Quantity of } \\
\text { vacancies declared } \\
\text { by employers }\end{array}$ & $\begin{array}{c}\text { The number } \\
\text { of registered } \\
\text { unemployed }\end{array}$ \\
\hline Veterinarian, chief veterinarian & 970 & 9 \\
\hline Medical specialist sister (nurse) & 377 & 2 \\
\hline Livestock specialist, chief livestock specialist & 385 & 2 \\
\hline Specialist doctor & 233 & 17 \\
\hline Accountant, chief accountant & 307 & 1 \\
\hline Agronomist, chief agronomist & 180 & 6 \\
\hline Engineer & 178 & 3 \\
\hline Foreman of a production team & 125 & 1 \\
\hline Psychologist & 118 & 17 \\
\hline
\end{tabular}

Source: based on author's calculations.

The main motive for labour migration is the search for a higher level of income. Therefore, social techniques to prevent internal and external migration are primarily associated with a change in the wage system. Both quantitative and qualitative methods are used in the country. Quantitative mechanisms are associated with the differentiation of wages for individual organizations. For example, in order to consolidate young specialists in the field, they are assigned high premiums: often young doctors without work experience receive the same salary as specialists with 15 years of experience. This allows to partially resolve the imbalance in the labour market but does not have a long-term effect.

Qualitative mechanisms are associated with the transformation of the entire wage system. The main problems in the current wage system in Belarus are: insufficiently effective differentiation of tariff categories, employee disinterest in advanced training due to approximately equal tariff salaries, and the inefficient incentive function of additional payments. As it happens, any work in the country is paid approximately the same (for example, the difference in the salary of a driver and a doctor in Belarus is $35 \%$, while in Germany - $174 \%$, in the USA - $261 \%$, in Brazil - 172\%). This situation, on the one hand, significantly reduces the motivation of people to choose highly qualified professions, and, on the other hand, makes them look for highly qualified specialist positions at a decent level of remuneration abroad.

Currently, a number of legal measures are being taken to solve this problem. Thus, according to the Decree of the President of the Republic of Belarus "On the wage of employees of state organizations", from 2020 the tariff grid with 18 digits will be used for the calculation of wages, previously a tariff grid with 27 digits was used. The wage of employees of state organizations will consist of three components: 
salary, incentive payments (bonuses, allowances), compensatory payments (various kinds of surcharges). Under the new system, the number of normative legal acts that respond to this field of activity will be reduced, and the financing of the budget sphere will be built on the principle that more funds will be allocated for each following year than in the previous period (Morozova, 2019: 126). However, employees of state organizations do not believe that these innovations will bring a positive result. They are sure that their salary, on the contrary, will decrease. This is primarily due to the low awareness of citizens about innovations in the law. In general, communication between authorities and citizens of Belarus in various areas of social policy is ineffective.

\section{Social policy in the sphere of communication}

The communication problem is associated with the growing need in society to build open and effective interaction between the population and the government. The quality of communication between the "power" and "society" is one of the key characteristics of the level of development of the political system and are an indicator of the effectiveness of the social policy of the state. Communication strategies are an effective way to increase mutual trust between society and political institutions (Smolyanko, Chausov, 2019).

There are certain communication channels between the state and society functioning in Belarus. The main form of interaction between government bodies and the population is to work with citizens' appeals. It is implemented in the form of personal receptions, holding meetings with groups, direct telephone lines, hotlines, etc. However, opinion polls show that the population is not always satisfied with the work of local authorities in this direction. The reasons are: inattentive attitude to the problems of residents, poor-quality work with citizens' appeals, a failure of local authorities to fulfil promises, inoperability to solve problems, formality in working with citizens' appeals, the incompetence of local authorities, insufficient public awareness campaigns, the closed decisions of local authorities and the ignoring of the opinions of residents of the region. In addition, the existing period of consideration of appeals (30 days) does not correspond to the dynamics of modern communication and is perceived by the population as slowness of the state.

However, somethings are indeed changing: e-government, for example, is developing in Belarus. The main goal is to increase the openness and efficiency of government actions. Electronic forms and other methods of interaction can replace visits to government organizations, telephone calls and the sending of paper messages. However, these forms of communication are extremely poorly utilised: less than a third of the population have experience making government payments online (taxes, fines, duties); only every tenth citizen visited the websites of local 
authorities and often only a single portal in order to obtain necessary information; $8.3 \%$ of the population have filed completed documents electronically. The main reasons for citizen's low use of the Internet to interact with local authorities are the preference for a more familiar form of communication: personal interaction, as well as a lack of knowledge necessary for this form of interaction. The development of Internet technologies necessitates the widespread introduction of one-click communication capabilities and the expansion of dialogue options on government agencies' websites (online receptions, online rating and rating systems, video messages, etc.).

The regulatory impact assessment system is designed to ensure citizen participation in the development of legislative acts planned for adoption, but it also works inefficiently. This is due to a number of unresolved issues: the methodological recommendations for working with regulatory impact assessment have not been adopted; the list of regulatory acts has not been defined; public discussion has not taken place, which will be an obligatory stage for its adoption by the rule-making body; the mechanism for the implementation of proposals received in the course of public discussion has also not been defined. Deficiencies in the development of the regulatory impact assessment institution can be observed on the website of the Legal Forum of Belarus. For example, as part of the discussion of a number of projects, the site does not publish information on the considered and rejected proposals expressed during the public discussion. It remains unclear which of the comments and suggestions of citizens were taken into account when preparing the document, and which were rejected.

One form of communication between the government and society is to hold "single days of informing", during which employees of organizations attend a lecture on a specific topic. However, the topics that are submitted for discussion are not relevant for the population; therefore many perceive this event as a waste of time and consequently, they are not in high demand. The authorities are afraid to bring up for discussion the most important social issues that concern the population. Government officials are often not able to competently explain the situation due to a lack of communication skills. The activities of the organizers of the "single days of informing" are perceived by citizens primarily as old-fashioned management methods.

The political and social activity of the population is reflected in such a form of interaction as self-government. This form is extremely flexible and as close as possible to the population (Esmantovich, Esmantovich, 2017: 137). However, the Belarusian population is characterized by a low degree of awareness about the work of local self-government: only a third of the population is aware of the functioning of such a type of management. In addition, citizens are poorly involved in the activities of local self-government: only $11 \%$ of the population participate in local assemblies; whereas only $6 \%$ of citizens participate in the organization and conduction of elections to the local Council of Deputies; almost no one participates in local referenda, discussion 
of socio-economic development programs and draft decisions of local councils of deputies (Esmantovich, Esmantovich, 2017: 139).

At present, among the residents of Brest, a good response is received by direct communication of the government with the population. For example, the chairman of the Brest City Executive Committee has been practising communication with Brest residents in an open dialogue format for several years. In 2019, the mayor held five meetings with Brest residents, during which he answered questions important to the city and immediately instructs special services to solve specific problems of the city residents. Citizens are actively asking questions, enthusiastically speak about the problems solved by the mayor and his innovative experience in interacting with the population, and are proud of the official's actions. The number of resolved issues is growing, along with credibility and trust in the mayor of the city.

Thus, in order to increase mutual trust between society and the state, it is advisable to: inform the public about the policies pursued, so that this information is communicated to each citizen; send messages to the public in a simple and understandable way; provide citizens with possible options for alternatives and bring the public decision to the most rational option in terms of public benefits in the future; abandon the direct imposition of decisions; take an active part in open discussions of issues. This will allow to gradually move away from paternalistic expectations and develop the constructive activity of citizens.

The decrease in social activity is associated with the emerging negative problems of the formation of democracy and the formation of civil society. The low level of social activity in political life leads to a decrease in confidence in government institutions, as a result of which negative social moods are growing (Kostina, 2019: 79).

\section{Social policy in the social and labour sphere}

Social policy in the social and labour sphere is connected with the development of an innovative economy and the processes of robotization and automation in industry. This leads to excessive employment in enterprises, because many professions have disappeared and replaced by robots. This, in turn, leads to the emergence of new professions, therefore, it is necessary to transform the system of education and training of workers. These processes are a global trend in terms of the development of the world economy in the direction of the sixth technological order (Kroytor, 2019: 59).

Most of the employed population in Belarus works in private enterprises. As such, in 2019 the number of employees in private enterprises was $60 \%$, while the number of employees in state-owned enterprises was $40 \%$. Private and public 
companies use different mechanisms for adapting to automation and robotization processes. Private companies are increasingly resorting to job cuts; conversely, public companies use traditional social technology to solve the problem of excessive employment: there is widespread hidden unemployment. Workers work part-time or for long periods they stay on unpaid work leave. There are positive and negative consequences to this. The negative consequences are a deterioration in the material situation and purchasing power of the population, as well as a decrease in qualifications, and the weakening labour motivation of employees. In addition, underemployment leads to underproduction and a reduced gross domestic product compared to its potential level, since it represents an inefficient and incomplete use of employed labour resources. At the same time, excessive employment helps prevent mass unemployment, maintain a minimum level of well-being of the population and thereby ensuring at least a minimum level of consumption, as well as maintaining the human resources of the economy. It should be noted that this form of employment to some extent helps to increase the motivation of employees to change their position through advanced training, retraining, and also stimulates entrepreneurial activity (Syroyed, Gromyko, 2018).

Hidden unemployment is very difficult to gauge. One of the methods is to analyse statistical data for the following categories of workers: persons with part-time work; persons on work leave and without pay at the initiative of the employer. In 2018 about 48 thousand people worked part-time in large and medium-sized enterprises: in agriculture -4.6 thousand people; in the food industry -3.6 thousand people; in light industry -7.2 thousand people; in construction - 11.2 thousand people. For the same period, 32.5 thousand people were sent on leave without salary (Work and employment in the Republic of Belarus: statistical collection, 2018).

The problem of underemployment is particularly relevant for single-industry towns with one or two city controlled enterprises. The real economic condition of many city controlled enterprises is such that only one-third of the available staff of their labour resources is needed to carry out the current volume of industrial production. However, most government organizations cannot fire redundant workers because the Belarusian economy is socially oriented. In addition, many enterprises are not able to fulfil the requirements for monetary compensation for workers who have been made redundant.

Social technology for maintaining excessive employment in order to prevent mass unemployment is an intermediate tool, allowing only to delay the negative consequences associated with the extinction of professions. The transformation of the HR technologies at enterprises will make it possible to ensure the necessary level of qualifications of employees without the need to reduce or transfer them to part-time work.

Among HR technologies for development, we especially note the system of advanced training. In 2019 about 10\% of all employees were involved in educational 
programs, most of them took advanced training courses. However, the material and technical support, personnel, content and teaching methods in the framework of educational programs do not meet modern requirements and do not provide training for specialists of a sufficiently high level. The reason for this is the fundamental nature of the educational system, which does not allow for a quick response to innovative changes and the training of specialists of modern high-tech production.

Practice-oriented HR technologies should be improved. For example, it is possible to activate the personnel technology of mentoring. It is aimed at professional development and the training of an employee for the independent fulfilment of labour functions and the acquisition of specific professional knowledge and skills. In sociological researches personnel services workers point out the positive impact of mentoring in the organization: professional and career growth of employees, shortening the period of professional and social adaptation, increasing the efficiency of the structural unit (Semerikova, 2017: 167). However, in the Republic of Belarus there is no legislative support for the institution of mentoring, there are only local regulatory legal acts that determine the practice of its application. In addition, the mentor motivation system needs to be improved. Today, even in those few organizations where mentoring is enshrined in regulatory legal acts, the implementation mechanism and extremely low material remuneration create conditions for a high staff turnover rather than for retaining young specialists in the field.

At present, distance learning is actively developing, which allows employees to acquire new knowledge and increase their professional competence; it saves time and reduces costs, allows them to improve the quality of training through the use of modern tools and technologies.

Personnel assessment technologies are also able to increase labour productivity and employee motivation. However, innovative methods should be sought, since the existing system of employee certification is more formal and does not have any effect on the professional growth of employees. Using the competency-based approach in the certification process will improve this HR technology. A set of competencies (personal-business and professional qualities) sets the standard for the necessary knowledge, skills and abilities to fulfil duties within the framework of the position. The assessment of competencies can be carried out by various methods: testing, interviewing, associative experiment, qualification card, etc. A competency-based approach in assessing employees allows one to diagnose the professional qualities of an employee, identify gaps in qualifications and determine the necessary steps to address them.

It seems effective to include the released public sector workers in business. In order to regulate the development of small and medium-sized businesses in Belarus, the state has reduced the number of administrative procedures: a lot of reforms have been carried out together with entrepreneurs. However, sociological research shows that entrepreneurs complain about the conditions for doing business in Belarus: high 
tax rates; complex licensing and insurance processes, frequent inspections, unequal conditions for public and private organizations; unstable legislation (Belarusian business of 2016..., 2016). So, in the Doing Business ranking for 2019, the position of Belarus immediately fell by 12 points (from 37 to 49 places) compared to 2018 . Among the ten criteria by which the overall rating is considered, Belarus has the worst indicators for the following: obtaining loans (104 ${ }^{\text {th }}$ place), taxation $\left(99^{\text {th }}\right.$ place $)$ and protecting minority investors $\left(79^{\text {th }}\right.$ place).

In order to accelerate the pace of the formation of a new business, as well as the growth and competitiveness of small and medium enterprises, the institutional conditions for doing business should be improved. It is also important to increase the effectiveness of business associations, the main tasks of which are to establish interaction between entrepreneurs and government in order to make joint decisions, support and advise entrepreneurs on the legal regulation of entrepreneurial activity, and assist in international cooperation. The membership of small and medium enterprises in business unions over the past 10 years remains extremely low.

In the conditions of globalization and the strengthening of the influence of the private sector on the world economy, it is necessary to look for a compromise between regulating and the economic function of the state. This needs to be done to solve the problem of privatization within certain spheres of the economy within the country and business liberalizations, to create an equal competitive environment for the private companies and the state enterprises, and to develop institutes of public-private partnership. In this regard, the main condition for the normal functioning of a market economy is constructive dialogue between the state and business.

\section{Conclusions}

The main condition for the country's socio-economic development is a high human potential, because the professional and motivational competence of workers opens up significant reserves for innovative transformations and activates the development of modern business organizations. Belarusian state is currently facing demographic, communication, technological and many other challenges. Therefore, it has to solve complex problems: on the one hand, maintain the stability of the social structure and prevent its destruction; on the other, provide the necessary leap in development for innovative qualitative changes. At the same time, the key goal is to preserve the country's physical, intellectual and moral potential, stimulate the reproduction of the workforce and provide conditions for personal development.

1. In the field of demography, the social policy of the state should be aimed at searching for indirect measures to increase social guarantees for women in 
order to stimulate fertility and encourage in the society the traditional values of family and children. Changing the mechanism for calculating pension payments to Belarusians is also relevant today. It would help to reduce the demographic burden on the working population.

2. In the face of growing external and internal migration, the development of the new state measures to prevent the outflow of highly qualified specialists, the effective mechanisms to encourage the return of students who received education abroad, and the creation of good conditions for professional activity in all areas of Belarus is needed. Changing the mechanism of the payroll is also relevant to solving the problem of labour migration.

3. Social policy in the labour sphere within the current conditions of the development of an innovative economy and processes of automation and robotization should be aimed to maintain the labour potential. It is necessary to improve the existing personnel technologists (development of the institution of mentoring, popularization of the distance learning for employees) and introduce the innovative personnel technologies. Personnel assessment technologies based on a competency-based approach are also able to increase labour productivity and employee motivation.

4. The effectiveness of communication between society and the state should be also increased. The state should inform the public about the current state policy, send messages to the public in a simple and understandable way, provide citizens with possible options for alternatives, take an active part in the organization of the public discussions of the state initiatives before making them. This will increase people's trust in government, will allow to gradually move away from paternalistic expectations and develop the constructive participation of citizens. Also, such steps can prevent Belarusian state from such instances as the mass rejection of such state actions as increasing the pension age, taxes and prices. French experience of the "yellow vests" gave a good lesson to all governments how to communicate with the citizens.

\section{References}

Belarusian business of 2016: state, trends, prospects. 2018, http://www.research.by/ analytics/businessbook/16/ (accessed 25.10.2019).

Chubarova, T.V. 2019. Modern paternalism for the mainstream product: social problems, individual solutions. Social Sciences and the Present 6, pp. 27-39.

The demographic situation in Belarus remains unstable so far. 2019, https://1prof.by/news/ obshhestvo-i-profsoyuzy/irina-kostevich-demograficheskaya-sit/ (accessed 20.10.2019).

Demographic yearbook of the Republic of Belarus: statistical book. 2019, https:// www.belstat.gov.by/upload/iblock/357/3571fdc0efdfdb1b8c6c615d0f0b76e3.pdf (accessed 10.01.2020). 
Esmantovich, I.I., Esmantovich, E.I. 2017. Local government and development of public activity of citizens. News of the Gomel state university name F. Skorina 2, pp. 136-142.

In Belarus there is not enough money for pensions. 2017, https://news.myseldon.com/ru/ news/index/171718375 (accessed 20.12.2019).

Kostina, L.N. 2019. Increasing public activity as a means of implementing state social policy. In: Civil Society, Government and Business: The Role of Higher Education in the Interaction Dialogue. Kursk: Publishing house of the Kursk Institute management, economics and business, p. 124.

Kroytor, S. 2019. Digitalization economies as factor transformations labour markets. Science and Innovations 6, pp. 58-63.

Law of Republic of Belarus «About Provision of Pensions»1992, http://www.pravo.by/ document/?guid=3961\&p0=V19201596 (accessed 20.11.2019).

Lozovova, L.A., Nemashkalova, K.G. 2014. Analysis of foreign models of social policy. In: Public and Municipal Administration, https://cyberleninka.ru/article/n/analizzarubezhnyh-modeley-sotsialnoy-politiki/viewer (accessed 30.08.2019).

Morozova, N.N. 2019. Innovations in compensation of workers of the budgetary sphere. Problem of Forecasting and State Regulation of Social and Economic Development 2, pp. $125-126$.

Pliskevich, N.M. 2019. Archaic of institutions and the archaic of paternalism: is there a relationship? VTE 1, pp. 100-116.

Pushkevich, S.A. 2018. Trends of development of external labor migration of the population of Republic of Belarus: statistical and sociological analysis. Sociological Almanac 9, pp. 304-315.

Rudak, A.A. 2019. A problem of intellectual migration of youth from Republic of Belarus. Problems of Forecasting and State Regulation of Social and Economic Development 2, pp. 147-148.

Semerikova, M.G. 2017. The prospects of introduction and realization of institute of mentoring in public authorities and the organizations of Republic of Belarus. In: Increase in Overall Performance of Government in the Conditions of Current Trends and Calls: Collection of Scientific Works. Minsk: Academy of management under the President of the Republic of Belarus, pp. 164-173.

Smolyanko, O., Chausov, Y. 2019. Interaction of local authorities and noncommercial the organizations in Belarus: legal regulation and practice. Minsk: Knigazbor.

Statistics of the Ministry of Labour and Social Protection of Republic of Belarus. 2019, http://mintrud.gov.by/ru/rynok (accessed 20.10.2019).

Syroyed, N.A., Gromyko, T.N. 2018. Labor market and personnel management, http:// lib.i - bteu.by/bitstream/handle.pdf (accessed 8.09.2019).

Work and employment in Republic of Belarus: statistical collection. 2018, https:// www.belstat.gov.by/upload/iblock/ed5/ed53c414ac383e1f65fd78675052dcc1.pdf (accessed 10.11.2019).

Workers from Belarus and Asia drive the Ukrainian migrants out of the Polish labor market. 2018, https://finance.tut.by/news607167.html (accessed 10.12.2019).

Zagorets, V., Zagorets, I. 2019. Methodological aspects of the research population shift processes. Journal of International Law and International Relations 1, pp. 72-84. 